\title{
The effect of insulin on the vascular reactivity of isolated resistance arteries taken from healthy volunteers
}

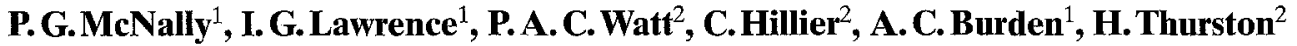 \\ ${ }^{1}$ Department of Diabetes, University of Leicester, Leicester Royal Infirmary, Leicester, UK \\ ${ }^{2}$ Department of Medicine, University of Leicester, Leicester Royal Infirmary, Leicester, UK
}

\begin{abstract}
Summary Impaired reactivity of the resistance vasculature may contribute to the development of diabetic microangiopathy by altering microvascular haemodynamics. This study investigates the acute effects of insulin on the contractility and relaxation properties of isolated human resistance arteries $(<300 \mu \mathrm{m}$ internal diameter) taken from gluteal subcutaneous fat of 33 (18 male: 15 female) normotensive healthy volunteers (supine blood pressure 115.6 $\pm 1.6 /$ $70.0 \pm 1.5 \mathrm{mmHg}$ [mean $\pm \mathrm{SEM}$ ], with no family history of hypertension or diabetes mellitus. Resistance arteries were mounted in a small vessel myograph to measure isometric tension. Contractile responses to noradrenaline were reduced after incubation in $1 \mathrm{mU} / \mathrm{ml}$ of insulin for $20 \mathrm{~min}(p<0.01$; Group 1$)$. Increasing concentrations of insulin were found to reduce the contractile response to noradrenaline in a dose-dependent manner (Group 2; $0.1 \mathrm{mU} / \mathrm{ml}$ by $8 \%[p<0.01], 1 \mathrm{mU} / \mathrm{ml}$ by $17 \%[p<0.02]$ and
\end{abstract}

$10 \mathrm{mU} / \mathrm{ml}$ by $22 \%[p<0.01])$. Sensitivity to insulin $\left(E_{50}\right)$ only decreased at the highest concentration of insulin. However, acetycholine-induced relaxation was not altered by insulin (Group 2). Time control studies (Group 3) showed that contractile and relaxation responses over the 4-h study period were unchanged. Furthermore, the length of time the vessels were exposed to insulin did not progressively impair responses (Group 4). These findings suggest that insulin may induce abnormalities in vascular smooth muscle contractility, a factor that may contribute to or exacerbate the abnormal haemodynamics observed in the capillary microcirculation of numerous vascular beds in diabetes. [Diabetologia (1995) 38: $467-473]$

Key words Insulin, resistance arteries, vascular reactivity, EDRF.
An increase in capillary blood flow and pressure has been shown in a diverse range of microcirculatory beds in patients with diabetes mellitus, including the kidney [1-4], retina [5], skin [6, 7] and forearm [8]. These changes also manifest at an early stage after diagnosis before there is clinical evidence of structural

Received: 6 June 1994 and in revised form: 30 September 1994

Corresponding author: Prof. H.Thurston, Department of Medicine, University of Leicester, Clinical Sciences Building, Leicester Royal Infirmary, P.O. Box 65, Leicester, LE2 7LX, UK

Abbreviations: PSS, Physiological salt solution; $\mathrm{mN} / \mathrm{mm}$, millinewtons per millimetre; $\mathrm{ED}_{50}$, dose required to produce $50 \%$ of the maximum response; NIDDM, non-insulin-dependent diabetes mellitus; IDDM, insulin-dependent diabetes mellitus. injury $[1,2,8]$. The mechanisms underlying these changes are not known; however, a change in the vascular reactivity of the resistance vessels may play a contributory role by permitting alterations in regional haemodynamics. Thus, a recent study demonstrating nailfold capillary hypertension in young insulindependent diabetic (IDDM) patients suggested that the increased blood flow results from pre-capillary dilation [9].

Although there is considerable evidence that the development of diabetic microangiopathy relates to the degree and duration of hyperglycaemia, much less is known about the influence of insulin on microvascular function. Hyperinsulinaemia has been associated with the pathogenesis of microvascular and macrovascular injury in patients with diabetes [10] 
and also in the aetiology of hypertension in patients with non-insulin-dependent diabetes (NIDDM), obesity and essential hypertension [11]. Insulin is known to influence cardiovascular function independent of its hypoglycaemic action. Intravenous administration of insulin to patients with diabetes produces a decrease in plasma volume [12] and circulating albumin concentration [13]. In patients with diabetic autonomic neuropathy intravenous insulin induces a reduction in both blood pressure [14] and peripheral vascular resistance [15] not found in normal subjects [16]. In in vitro studies, insulin attenuates systemic and regional vascular reactivity in dogs [17] and inhibits noradrenaline- and angiotensin II-induced contractions in isolated rabbit femoral artery and vein [18]. On the other hand, depending on which vascular bed is studied, both vasodilator and vasoconstrictor responses can be elicited in the dog during infusions of insulin [17]. However, there are limited data on the microvascular effects of insulin in man. Euglycaemic hyperinsulinaemia in healthy subjects has been reported to augment cardiovascular reactivity to noradrenaline [19], while no effect was demonstrated with angiotensin II $[19,20]$. Moreover, acute increases in plasma insulin within the physiological range have shown conflicting responses in forearm vasodilation [21, 22], but with no increase in blood pressure despite increased sympathetic neural outflow [21] and a marked increase in forearm noradrenaline release [22]. Local hyperinsulinaemia (using a brachial artery infusion) attenuates neurogenic vasoconstriction induced by lower body negative pressure [23] and also the pharmacological vasoconstriction of phenylephrine and angiotensin II [24]. Most studies have shown no changes in baseline forearm vascular resistance detected during intra-arterial insulin infusion [23-26] suggesting that a direct vasodilatory effect of insulin is unlikely.

Administration of insulin via the subcutaneous route results in peripheral hyperinsulinaemia in patients with IDDM [27]. NIDDM is also characterised by high levels of circulating endogenous insulin. It is possible that abnormal reactivity of the resistance vasculature resulting from hyperinsulinaemia may contribute to or exacerbate the changes in microvascular haemodynamics described in patients with diabetes. The resistance vasculature is the most important system of vessels controlling tissue perfusion, protecting the microcirculation from the deleterious effects of high blood flow and maintaining a normal intracapillary hydrostatic pressure. The purpose of the present study was to determine whether vascular responses of isolated subcutaneous resistance vessels taken from healthy subjects are acutely modulated by insulin.

\section{Subjects and methods}

Subjects. Thirty-three normotensive healthy volunteers (supine blood pressure, $115.6 \pm 1.6 / 70.0 \pm 1.5 \mathrm{mmHg}$ [mean \pm SEM] using a random zero sphygmomanometer), within $10 \%$ of their ideal body weight, taking no vasoactive medication and without a family history of hypertension or diabetes were studied.

Four study groups were studied: Group 1 (ten subjects), Group 2 (ten subjects), Group 3 (eight subjects) and Group 4 (five subjects) [see protocol below].

The study protocol was approved by the local ethical committee and all subjects gave informed written consent.

Preparation of arteries. Resistance arteries were dissected from a biopsy of skin and subcutaneous fat from the gluteal region (approximately $2 \mathrm{~cm}$ long $\times 0.5 \mathrm{~cm}$ wide $\times 1 \mathrm{~cm}$ deep) taken under local anaesthesia $(3 \mathrm{ml}$ to $5 \mathrm{ml}$ of $2 \%$ lignocaine hydrochloride). Two segments of artery ( $2 \mathrm{~mm}$ in length) from each biopsy were mounted as ring preparations on two $40 \mu \mathrm{m}$ stainless steel wires in a small vessel myograph [JP Trading, Aarhus, Denmark] [28]. One wire was attached to a force transducer to measure isometric tension and the other wire to a micrometer. This arrangement enables wall tension to be measured at a predetermined internal diameter. The vessels were bathed in physiological salt solution (PSS composition (in $\mathrm{mmol} / \mathrm{l}) \mathrm{NaCl}, 118 ; \mathrm{KCl}, 4.5 ; \mathrm{CaCl}_{2}, 2.5 ; \mathrm{MgSO}_{4} \cdot 7 \mathrm{H}_{2} \mathrm{O}$, $\mathrm{KH}_{2} \mathrm{PO}_{4}, \mathrm{NaHCO}_{3}, 25$ and glucose 6), maintained at $37^{\circ} \mathrm{C}$ and gassed with $5 \% \mathrm{CO}_{2} / 95 \% \mathrm{O}_{2}$ to achieve a pH of 7.4 [23]. After a 60 -min equilibrium period the length tension characteristics for each vessel, using the LaPlace equation $(P=T / r$ where $P$ is the transmural pressure, $T$ is the tension and $r$ is the internal radius of the vessel), was determined and the internal diameter set to $0.9 \times \mathrm{L}_{100}$ where $\mathrm{L}_{100}$ is the calculated internal diameter the vessel would have in vivo when relaxed and under a transmural pressure of $13.3 \mathrm{kPa}(100 \mathrm{~mm} \mathrm{Hg})$. Previous studies have shown that the generated force is maximal at this setting [28].

Protocol: After normalisation, the vessels were maintained in PSS at $37^{\circ} \mathrm{C}$ for a further $60 \mathrm{~min}$. In the first group (pilot study) of 10 patients (Group 1), a cumulative dose contraction response to noradrenaline $\left(10^{-8} \mathrm{~mol} / 1\right.$ to $\left.3 \times 10^{-5} \mathrm{~mol} / \mathrm{l}\right)$ was performed in the presence of cocaine $\left(10^{-6} \mathrm{~mol} / \mathrm{l}\right)$ before and $20 \mathrm{~min}$ after the addition of $1.0 \mathrm{mU} / \mathrm{ml}$ insulin.

In the second series of 10 patients (Group 2), a cumulative dose contraction response to noradrenaline was performed in the presence of increasing doses of insulin $(0.01,0.1,1.0$, $10 \mathrm{mU} / \mathrm{ml}$ ). The vessels were exposed to each concentration of insulin for at least $20 \mathrm{~min}$ before assessing vascular responses. Relaxation studies were performed in maximally contracted vessels (noradrenaline $10^{-5} \mathrm{~mol} / \mathrm{l}$ ). After a steady plateau of contraction was achieved (2-3 min) cumulative doses of the endothelium-dependent vasodilator acetylcholine $\left(10^{-8} \mathrm{~mol} / 1\right.$ to $10^{-5} \mathrm{~mol} / \mathrm{l}$ ) were added to the bath and the relaxation observed.

In the third series of eight patients (Group 3), the same protocol used in the second series (Group 2) was performed, without the addition of insulin to act as time controls.

Finally, in the fourth series of five patients (Group 4), all cumulative dose contraction curves and acetylcholine relaxation curves were performed in the presence of $0.1 \mathrm{mU} / \mathrm{ml}$ insulin. The insulin remained in the bath and both the contraction and relaxation curves were repeated at hourly intervals for up to $4 \mathrm{~h}$ to observe whether there was a decrease in response related to the incubation time with insulin. 
P. G. McNally et al.: Effects of insulin on vascular reactivity

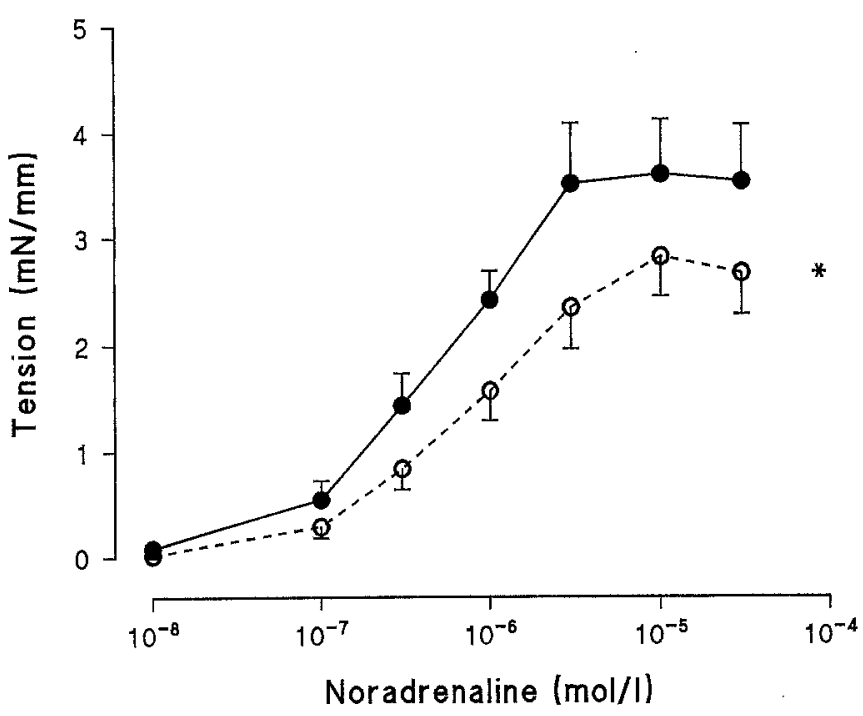

Fig. 1. Shows the contractile response to noradrenaline before ( ) and after the addition of $1.0 \mathrm{mU} / \mathrm{ml}$ insulin (O). $* p<0.001$

All drugs (Sigma Chemical Co., Poole, Dorset UK) were dissolved in distilled water and diluted with PSS. The molarity is expressed as the final concentration in the bath.

\section{Statistical analysis}

The results from the two vessel segments were averaged to give one value for each individual. The group results were expressed as mean \pm SEM. The contractile forces were expressed as force per length of vessel $(\mathrm{mN} / \mathrm{mm})$. Relaxation was expres- sed as a percentage of the maximal contraction achieved with noradrenaline. The sensitivity to agonists was expressed as the dose required to produce $50 \%$ of the maximum response $\left(\mathrm{ED}_{50}\right)$. Differences between the cumulative dose response curves were compared by analysis of variance and differences between sensitivity $\left(\mathrm{ED}_{50}\right)$ by paired $t$-test, using Dunnett's correction for multiple comparisons, accepting $p<0.05$ as being significant.

\section{Results}

The normalised internal diameter of the arteries in all four groups was similar (Group 1, $247 \pm 16 \mu \mathrm{m}$; Group 2, $322 \pm 37 \mu \mathrm{m} ;$ Group 3, $317 \pm 17 \mu \mathrm{m}$ and Group 4, $304 \pm 28 \mu \mathrm{m}$ ). In the first study (Group 1), dose contraction responses to noradrenaline were significantly reduced after the addition of $1.0 \mathrm{mU} / \mathrm{ml}$ insulin (Fig. 1, Table 1). This was associated with no significant change in $\mathrm{ED}_{50}$ (Table 1).

In the second study (Group 2), increasing concentrations of insulin $(0.01$ to $10 \mathrm{mU} / \mathrm{ml})$ significantly depressed the response to noradrenaline in a dose-dependent manner (Fig. 2). Insulin (0.1 mU/ml) reduced the maximal response by $8 \% \quad(p<0.01)$, $1 \mathrm{mU} / \mathrm{ml}$ insulin by $17 \%(p<0.02)$ and $10 \mathrm{mU} / \mathrm{ml}$ insulin by $22 \%(p<0.01)$. With insulin concentrations of 0.1 to $1 \mathrm{mU} / \mathrm{ml}$, there was no alteration in the sensitivity to noradrenaline, there being no significant change in the $\mathrm{ED}_{50}$. However, at a concentration of $10 \mathrm{mU} / \mathrm{ml}$ insulin in the bath, there was a significant reduction in sensitivity to noradrenaline $(p<0.05)$ (Table 1). Acetylcholine caused a dose-dependent re-

Table 1. Maximum contractile and relaxation responses to noradrenaline (NA) and acetylcholine (ACh) with measurement of sensitivity $\mathrm{ED}_{50}$

\begin{tabular}{|c|c|c|c|c|}
\hline & $\begin{array}{l}\mathrm{NA} \max \\
(\mathrm{mN} / \mathrm{mm})\end{array}$ & $\begin{array}{l}\mathrm{NA} \mathrm{ED}_{50} \\
(\mu \mathrm{mol} / 1)\end{array}$ & $\begin{array}{l}\text { ACh max } \\
(\%)\end{array}$ & $\begin{array}{l}\mathrm{ACh} \mathrm{ED_{50 }} \\
(\mu \mathrm{mol} / 1)\end{array}$ \\
\hline $\begin{array}{l}\text { Study group } 1 \\
\text { No insulin } \\
1.0 \mathrm{mU} / \mathrm{ml} \text { insulin }\end{array}$ & $\begin{array}{l}3.59 \pm 0.49 \\
2.81 \pm 0.37^{\mathrm{c}}\end{array}$ & $\begin{array}{l}0.45 \pm 0.13 \\
1.40 \pm 0.41\end{array}$ & - & $\begin{array}{l}- \\
-\end{array}$ \\
\hline $\begin{array}{l}\text { Study group } 2 \text { (inst } \\
0.0 \\
0.01 \\
0.1 \\
1.0 \\
10\end{array}$ & $\begin{array}{l}\text { ation } \mathrm{mU}(\mathrm{ml}) \\
- \\
4.60 \pm 0.56 \\
4.21 \pm 0.59^{\mathrm{c}} \\
3.82 \pm 0.55^{\mathrm{b}} \\
3.61 \pm 0.50^{\mathrm{c}}\end{array}$ & $\begin{array}{l}- \\
0.57 \pm 0.13 \\
0.76 \pm 0.20 \\
0.95 \pm 0.21 \\
1.37 \pm 0.39^{\mathrm{a}}\end{array}$ & $\begin{array}{l}43 \pm 11 \\
52 \pm 12 \\
53 \pm 12 \\
58 \pm 12 \\
58 \pm 13\end{array}$ & $\begin{array}{l}0.40 \pm 0.16 \\
0.27 \pm 0.08 \\
0.17 \pm 0.05 \\
0.20 \pm 0.08 \\
0.27 \pm 0.15\end{array}$ \\
\hline $\begin{array}{l}\text { Control group } 3 \text { ( } \\
\text { 1st response } \\
\text { 2nd response } \\
3 \text { rd response } \\
\text { 4th response } \\
\text { 5th response }\end{array}$ & $\begin{array}{l}- \\
4.51 \pm 0.58 \\
4.39 \pm 0.53 \\
4.58 \pm 0.53 \\
4.54 \pm 0.47\end{array}$ & $\begin{array}{l}- \\
0.68 \pm 0.11 \\
0.76 \pm 0.14 \\
0.81 \pm 0.13 \\
1.10 \pm 0.19\end{array}$ & $\begin{array}{l}56 \pm 11 \\
60 \pm 9 \\
73 \pm 9 \\
79 \pm 8 \\
78 \pm 8\end{array}$ & $\begin{array}{l}0.16 \pm 0.05 \\
0.15 \pm 0.02 \\
0.16 \pm 0.03 \\
0.14 \pm 0.03 \\
0.15 \pm 0.04\end{array}$ \\
\hline
\end{tabular}

${ }^{\mathrm{a}} p<0.05 ;{ }^{\mathrm{b}} p<0.01 ;{ }^{\mathrm{c}} p<0.001$. Compared with first response using a Student's paired $t$-test with Dunnet's correction factor for multiple comparisons 


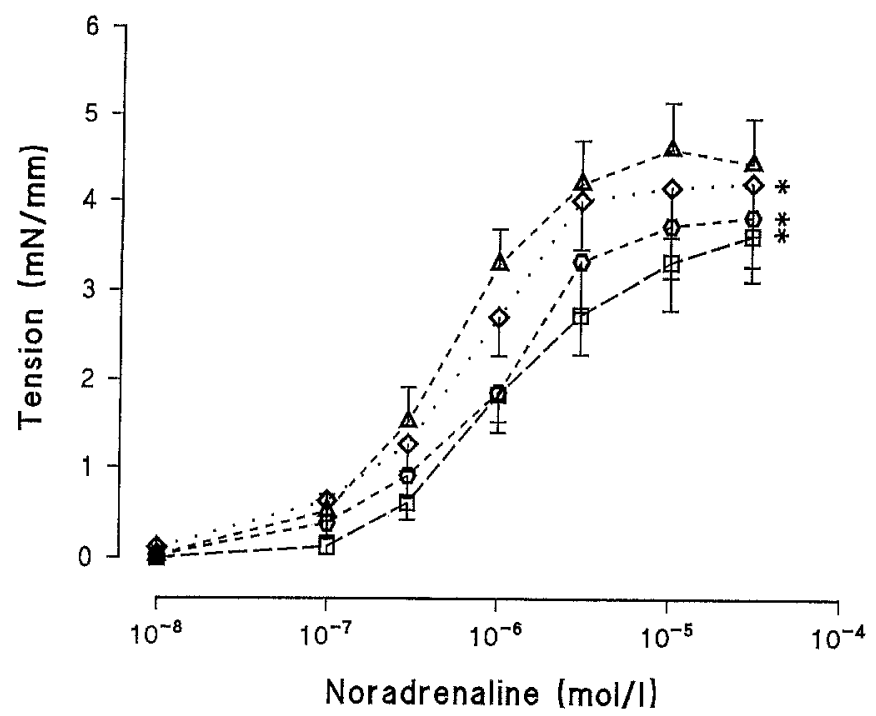

Fig. 2. Shows the contractile response to noradrenaline in the presence of $0.01 \mathrm{mU} / \mathrm{ml}(\triangle), 0.1 \mathrm{mU} / \mathrm{ml}(\diamond), 1.0 \mathrm{mU} / \mathrm{ml}(\mathbf{0})$ and $10 \mathrm{mU} / \mathrm{ml}(\square)$ insulin. ${ }^{*} p<0.05$

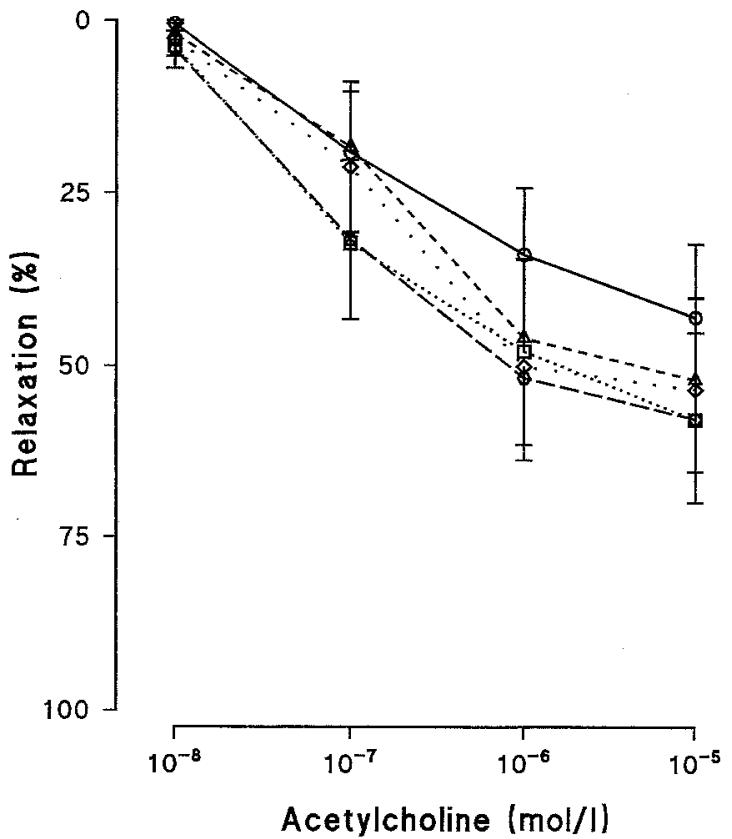

Fig. 3. Shows the relaxation response to acetylcholine in the absence of $(O)$ and in the presence of $0.01 \mathrm{mU} / \mathrm{ml}(\triangle)$, $0.1 \mathrm{mU} / \mathrm{ml}(\diamond), 1.0 \mathrm{mU} / \mathrm{ml}(\mathbf{O})$ and $10 \mathrm{mU} / \mathrm{ml}(\square)$ insulin

laxation of all precontracted vessels which was unaltered at any concentration of insulin (Fig. 3, Table 1).

The time control experiments (Group 3), showed no change in the contractile response to noradrenaline or the relaxation response to acetylcholine over the 4-h period of the study (Figs. 4 and 5, Table 1).

In the final group of experiments (Group 4), when the vessels were incubated with $0.1 \mathrm{mU} / \mathrm{ml}$ insulin for up to $4 \mathrm{~h}$, there was no alteration in the contractile response to noradrenaline (Fig. 6) or the relaxation response to acetylcholine (Fig. 7, Table 1). These re-

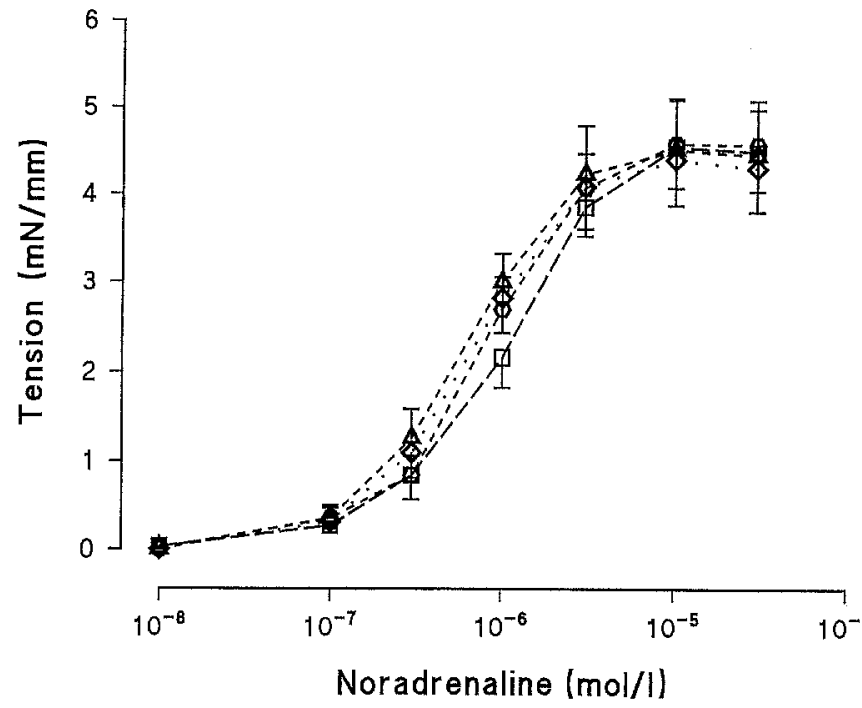

Fig. 4. Shows the contractile responses to noradrenaline at the first $(\triangle)$, second $(\diamond)$, third $(\mathbf{O})$ and fourth $(\square)$ exposures

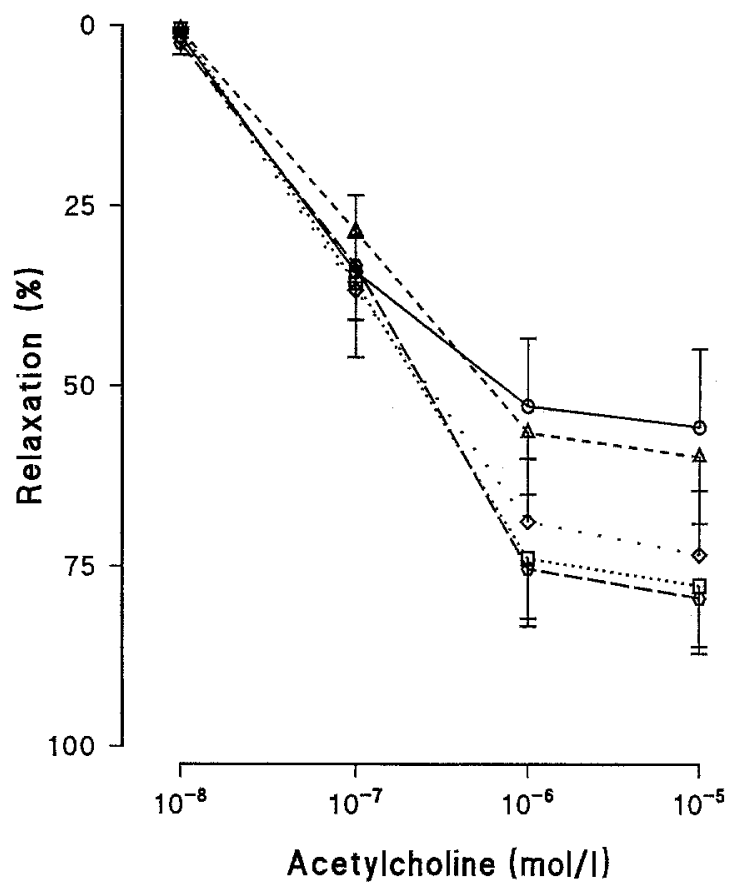

Fig. 5. Shows the relaxation responses to acetylcholine at the first $(0)$, second $(\triangle)$, third $(\diamond)$ and fourth $(0)$ and fifth $(\square)$ exposures

sults would indicate that the observed responses with increasing doses of insulin, to noradrenaline and acetylcholine, were not affected by the length of time the insulin was in the bath.

\section{Discussion}

This study demonstrates that acute exposure to insulin attenuates the vasoconstrictor response of isolated human subcutaneous resistance arteries to nora- 


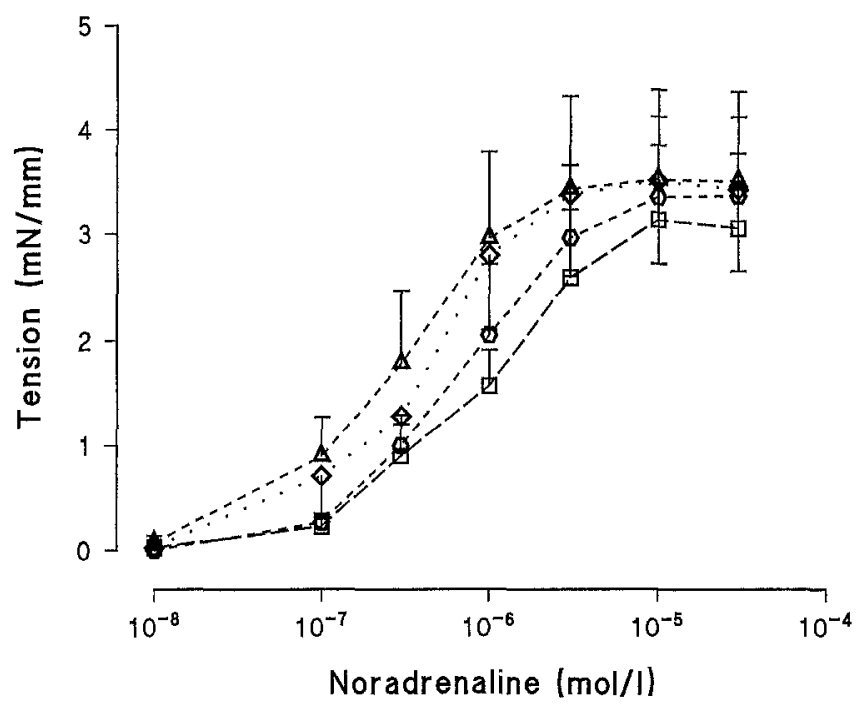

Fig. 6. Shows the contractile responses to noradrenaline in the presence of $0.1 \mathrm{mU} / \mathrm{ml}$ insulin at the first $(\Delta)$, second $(\diamond)$, third ( $\mathbf{0})$ and fourth ( $\square$ ) exposures

drenaline. By contrast, endothelium-dependent vasodilator responses to acetylcholine were preserved. These findings suggest that insulin may induce inhibition in vascular smooth muscle contractility, a factor that may contribute to or exacerbate the abnormal haemodynamics witnessed in the capillary microcirculation of numerous vascular beds in diabetes $[2,6$, 7]. Thus, it can be inferred that there will be less contraction of the resistance vessels for any degree of neurohumoral stimulation, leading to an increased blood flow to the capillary microcirculation, an increase in hydrostatic pressure and hence promote increased vascular permeability. These findings support earlier studies in animals which demonstrated similar impairment of contractile responses to noradrenaline in vascular smooth muscle and cardiac muscle $[18,29,30]$.

Although the cardiovascular effects of insulin in diabetic patients have been known for many years [14], the mechanisms underlying the changes in vascular reactivity are not well understood. Insulin has been shown to induce vasodilation in diabetic patients with autonomic neuropathy [31]. However, there have also been reports of increased pressor responses to vasoconstrictor agents in patients with diabetes [32-34]. Drury et al. [33] reported that the vascular response to angiotensin II was increased in IDDM patients without microvascular complications. However, impaired vascular responses to angiotensin II have been shown in patients with diabetes $[15,35]$. Recently, Wamback and Lui [36] demonstrated that insulin attenuated the vasoconstrictor response to a variety of agonists, including noradrenaline, serotonin and potassium chloride in rat mesenteric arterioles, suggesting that the action of insulin on vascular reactivity is not specific for a given

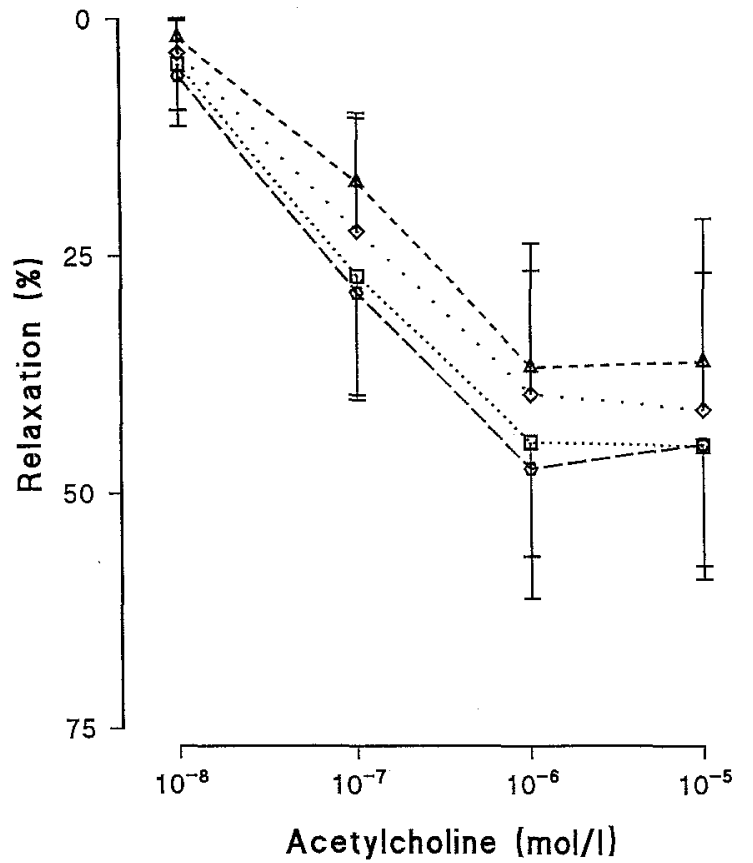

Fig. 7. Shows the relaxation responses to acetylcholine in the presence of $0.1 \mathrm{mU} / \mathrm{ml}$ insulin at the first $(\triangle)$, second $(\diamond)$, third (o) and fourth ( $\square$ ) exposures

receptor system. The present study indicates that insulin does not affect endothelium-dependent relaxation; moreover, insulin has been shown to relax the isolated canine carotid artery with and without an intact endothelium, suggesting that it acts on the vascular smooth muscle directly [37].

However, Wu et al. [38] have recently shown that insulin, and more potently insulin-like growth factor I, inhibits vasoconstriction in rat aortic rings (but increases splanchnic vasoconstriction); removal of endothelium abolished these effects, suggesting insulin and insulin-like growth factor I receptors mediate endothelial production of vasoactive agents. In the aortic rings, insulin-like growth factor I induced a dosedependent increase in cyclic GMP whilst the nitric oxide synthase inhibitor $\mathrm{L}-\mathrm{N}^{\mathrm{g}}$ monomethyl arginine (at a concentration that did not affect acetycholinemediated relaxation) inhibited the vasodilation; both these results implicate a role for increased nitric oxide production in the vascular responses to insulin and insulin-like growth factor I. The blunting of insulin-like growth factor I vasodilation by $\mathrm{N}^{\mathrm{g}}$-nitro-l-arginine methyl ester (another inhibitor of nitric oxide biosynthesis) has also been shown in the rabbit renal artery [39]. However, forearm studies showing decreased vasoconstriction to $\mathrm{L}-\mathrm{N}^{\mathrm{g}}$ monomethyl arginine in IDDM would suggest reduced nitric oxide synthesis $[40,41]$.

The mechanisms responsible for impaired vascular contractility to noradrenaline in the presence of insulin are not known. Alterations in several local vascular control mechanisms could conceivably contribute 
to the impaired response. Liang et al. [17] suggested that a beta-adrenergic dilator mechanism may be responsible after demonstrating that propranolol inhibited the skeletal muscle vasodilator response to a systemic insulin infusion. Similarly, in man an intra-arterial administration of propranolol prevented the forearm vasodilatation produced by a brachial artery infusion of insulin [26]. Alternatively, insulin may act via direct modulation of transmembrane cation exchange mechanisms. Thus, insulin has been shown to stimulate $\mathrm{Na}^{+} / \mathrm{K}^{+}$ATPase and the $\mathrm{Na}^{+} / \mathrm{K}^{+}$pump in a variety of tissues, including vascular smooth muscle [42-44]. Stimulation of the $\mathrm{Na}^{+} / \mathrm{K}^{+}$pump induces hyperpolarisation and thereby decreases calcium influx via voltage-operated channels [45]. In cultured rat vascular smooth muscle cells, insulin attenuates the peak intracellular calcium response to arginine vasopressin, by reducing calcium influx by both receptor and voltage-operated channels [46]: in contrast, there is an increased response to angiotensin II [47]. However, in both human and rat cells, insulin caused a marked increase in the rate of intracellular calcium recovery to baseline after agonist stimulation; this probably reflects insulin stimulation of plasmalemma $\mathrm{Ca}^{2+} /$ ATPase, sarcoplasmic reticulum $\mathrm{Ca}^{2+} / \mathrm{AT}$ Pase or both $[47,48]$.

The inhibitory effect of insulin on vasoconstrictor responses to noradrenaline questions the role hyperinsulinaemia plays in the development of hypertension in patients with essential hypertension and diabetes [11]. It is conceivable that chronic hyperinsulinaemia might induce vasoconstrictor responses since insulin stimulates vascular smooth muscle cell growth in animals and man $[49,50]$. Therefore, an insulin-induced structural change in resistance vessels may be responsible for increased peripheral resistance or lead to increased sensitivity to vasoconstrictor agonists. However, neither chronic hyperinsulinaemia associated with insulinoma in man [51] nor prolonged intravenous administration of insulin to dogs for up to 28 days [52] have been shown to elevate blood pressure.

In conclusion, this study shows that high concentrations of insulin impair vascular reactivity and this may contribute to diabetic microangiopathy by impairing vasoconstrictor responses in vivo, thereby allowing increased tissue blood flow and a rise in intracapillary pressure.

Acknowledgements. Dr. Lawrence is a Research Fellow supported by the British Heart Foundation. The authors wish to thank Ms. S. Martin for typing this manuscript.

\section{References}

1. Christiansen JS, Gammelgaard J, Tronier B et al. (1982) Kidney function and size in diabetics before and during initial insulin treatment. Kidney Int 21: 683-688
2. Zatz R, Dunn BR, Meyer TW, Anderson S, Rennke HG, Brenner BM (1986) Prevention of diabetic glomerulopathy by pharmacological amelioration of glomerular capillary hypertension. J Clin Invest 77: 1925-1930

3. Ditzel J, Junker K (1972) Abnormal glomerular filtration rate, renal plasma flow and protein excretion in recent and short-term diabetics. BMJ 2: 13-19

4. Parving H-H, Noer I, Deckert T et al. (1976) The effect of metabolic regulation on microvascular permeability to small and large molecules in short-term juvenile diabetics. Diabetologia 12: 161-166

5. Grunwald JE, Riva CE, Baine J, Brucker AJ (1992) Total retinal volumetric blood flow rate in diabetic patients with poor glycemic control. Invest Ophthal Vis Sci 33: 356-363

6. Tooke JE (1980) A capillary pressure disturbance in young diabetics. Diabetes 29: 815-819

7. Rayman G, Williams SA, Hassan AAK, Gamble J, Tooke JE (1985) Capillary hypertension and overperfusion in young diabetics. Diabet Med 2: 304A (Abstract)

8. Halkin A, Benjamin N, Dokto HS, Todd SD, Viberti GC, Ritter JM (1991) Vascular responsiveness and cation exchange in insulin-dependent diabetes. Clin Sci 81: 223-232

9. Sandeman DB, Shore AC, Tooke JE (1992) Relation of skin capillary pressure in patients with insulin dependent diabetes mellitus to complications and metabolic control. New Eng J Med 327: 760-764

10. Gwinup G, Elias AN (1991) Hypothesis: insulin is responsible for the vascular complications of diabetes. Medical Hypothesis $34: 1-6$

11. Reaven GM (1991) Relationship between insulin resistance and hypertension. Diabetes Care 14 [Suppl 4]: 33-38

12. MacKay JD, Hayakawa H, Watkins PJ (1978) Cardiovascular effects of insulin: plasma volume changes in diabetics. Diabetologia 15: 453-457

13. Gundersen HJG, Christensen NJ (1977) Intravenous insulin causing loss of intravascular water and albumin and increased adrenergic nervous activity in diabetics. Diabetes 26: 551-557

14. Page MMcB, Watkins PJ (1976) Provocation of postural hypotension by insulin in diabetic autonomic neuropathy. Diabetes 25: 90-95

15. Yamamoto M, Takata S, Yagi S et al. (1982) Haemodynamic effects of insulin. Excerpta Medica International Congress Series 577, 101: 224A (Abstract)

16. Miles DW, Hayter CJ (1968) The effect of intravenous insulin on the circulatory responses to tilting in normal and diabetic subjects with special reference to baroreceptor reflex block and atypical hypoglycaemic reactions. Clin Sci 34: 419-430

17. Liang CS, Doherty JU, Faillace R et al. (1982) Insulin infusion in conscious dogs. Effects on systemic and coronary hemodynamics, regional blood flows and catecholamines. J Clin Invest 69: 1321-1336

18. Yagi S, Takata S, Kiyok H et al. (1988) Effects of insulin on vasoconstrictive responses to norepinephrine and angiotensin $\mathrm{II}$ in rabbit femoral artery and vein. Diabetes 37: 1064-1067

19. Gans ROB, Bilo HJG, Maarschalkerweerd WWA, Heine RJ, Nauta JJP, Donker AJM (1991) Exogenous insulin augments in healthy volunteers the cardiovascular reactivity to noradrenaline but not angiotensin II. J Clin Invest 88: 512 518

20. Vierhapper H, Waldhausl W, Nowotny P (1983) The effect of insulin on the rise in blood pressure and plasma aldosterone after angiotensin II in normal man. Clin Sci 64: 383-386

21. Anderson EA, Hoffman RP, Balon TW, Sinkey CA, Mark AL (1991) Hyperinsulinaemia produces both sympathetic 
P. G. McNally et al.: Effects of insulin on vascular reactivity

neural activation and vasodilation in normal humans. $\mathrm{J}$ Clin Invest 87: 2246-2252

22. Lembo G, Napoli R, Capaldo B et al. (1992) Abnormal sympathetic overactivity evoked by insulin in the skeletal muscle of patients with essential hypertension. J Clin Invest 90: 24-29

23. Lembo G, Rendina V, Iaccarino G, Lamenza F, Volpe M, Trimarco B (1993) Insulin reduces reflex forearm sympathetic vasoconstriction in healthy humans. Hypertension 21: 1015-1019

24. Sakai K, Imaizumi T, Masaki H, Takeshita A (1993) Intraarterial infusion of insulin attenuates vasoreactivity in human forearm. Hypertension 22: 67-73

25. Natali A, Buzzigoli G, Taddei S et al. (1990) Effects of insulin on hemodynamics and metabolism in human forearm. Diabetes 39: 490-500

26. Creager MA, Liang CS, Coffman JD (1985) Beta-adrenergie mediated vasodilator response to insulin in the human forearm. J Pharmacol Exp Ther 235: 709-714

27. Werther GA, Jenkins PA, Turner RC et al. (1980) Twenty four hour metabolic profiles in diabetic children receiving insulin injections once or twice daily. BMJ 2: 414-418

28. Mulvany MJ, Halpern W (1977) Contractile properties of small arterial resistance vessels in spontaneously hypertensive and normotensive rats. Circ Res 41 (1): 19-26

29. Lee JC, Downing JE (1976) Effects of insulin on cardiac muscle contraction and responsiveness to norepinephrine. Am J Physiol 230: 1360-1365

30. Nudel DB, Lee JC, Downing JE (1977) Reciprocal inhibition of cardiac responses to norepinephrine and insulin. Am J Physiol 233: H665-H669

31. Takata S, Yamamoto M, Yagi S, Noto Y, Ikeda T, Hattori N (1985) Peripheral circulatory effects of insulin in diabetes. Angiology 36: 110-115

32. Christlieb AR, Janka H, Kraus B et al. (1976) Vascular reactivity to angiotensin II and to noradrenaline in diabetic subjects. Diabetes 25: 268-274

33. Drury PL, Smith GM, Ferriss JB (1984) Increased vasopressor responsiveness to angiotensin II in type 1 (insulindependent) diabetic patients without complications. Diabetologia 27: 174-179

34. Christlieb AR (1974) Renin, angiotensin and norepinephrine in alloxan diabetes. Diabetes 23: 962-967

35. McNally PG, Watt PAC, Rimmer T, Burden AC, Hearnshaw JR, Thurston H (1994) Impaired contraction and endothelium-dependent relaxation in isolated resistance vessels from patients with insulin-dependent diabetes mellitus. Clin Sci 87: 31-36

36. Wamback GK, Liu D (1992) Insulin attenuates vasoconstriction by noradrenaline, serotonin and potassium chloride in rat mesenteric arterioles. Clin Exp Hyper A14 (4): $733-740$

37. D'Orleans-Juste P, Dion S, Mizrahi J, Regoli D (1985) Effects of peptides and non-peptides on isolated arterial smooth muscles: role of endothelium. Eur J Pharmacol 114: 4-21
38. Wu H-Y, Jeng YY, Yue C-J, Chyu K-Y, Hsueh WA, Chan TM (1994) Endothelial-dependent vascular effects of insulin and insulin-like growth factor I in the perfused rat mesenteric artery and aortic ring. Diabetes 43: 1027--1032

39. Haylor J, Singh I, El Nahas AM (1991) Nitric oxide synthesis inhibitor prevents vasodilation by insulin-like growth factor I. Kidney Int 39: 333-335

40. Calver A, Collier J, Vallance P (1992) Inhibition and stimulation of nitric oxide synthesis in the human forearm arterial bed of patients with insulin-dependent diabetes. J Clin Invest 90: 2548-2554

41. Elliott TG, Cockcroft JR, Groop P-H, Viberti GC, Ritter JM (1993) Inhibition of nitric oxide synthesis in forearm vasculature of insulin-dependent diabetic patients: blunted vasoconstriction in patients with microalbuminuria. Clin Sci 85: 687-693

42. Ferrannini E, Taddei S, Santoro D et al. (1988) Independent stimulation of glucose metabolism and $\mathrm{Na}^{+} /$ $\mathrm{K}^{+}$exchange by insulin in the human forearm. Am J Physiol 255: E953-E958

43. Moore RD (1983) Effects of insulin upon ion transport. Biochem Biophys Acta 737: 1-49

44. Prakash TR, MacKenzie SJ, Ram JL, Sowers JR (1992) Insulin stimulates gene transcription and activity of $\mathrm{Na}^{+} / \mathrm{K}^{+}$ ATPase in vascular smooth muscle cells. Hypertension 20: 443 (Abstract)

45. Kahn AM, Seidel CL, Allen JC, O’Neil RG, Shelat H, Song $T$ (1993) Insulin reduces contraction and intracellular calcium concentration in vascular smooth muscle. Hypertension 22: 735-742

46. Standley PR, Zhang F, Ram JL, Zemel MB, Sowers JR (1991) Insulin attenuates vasopressin-induced calcium transients and a voltage-dependent calcium response in rat vascular smooth muscle cells. J Clin Invest 88: 1230-1236

47. Kim Y-C, Zemel MB (1993) Insulin increases vascular smooth muscle recovery from intracellular calcium loads. Hypertension 22: 74-77

48. Zemel MB, Johnson BA, Ambrozy SA (1992) Insulin-stimulated vascular relaxation. Role of $\mathrm{Ca}^{2+}$ ATPase. Am J Hypertens 5: 637-641

49. Pfeiffer B, Ditschuneit H (1981) Effect of insulin on growth of cultured human arterial smooth muscle cells. Diabetologia 20: $155-188$

50. Stout RW, Bielman EL, Ross R (1975) The effect of insulin on the proliferation of cultured primate arterial smooth muscle cells. Circ Res 36: 319-327

51. Tsutsu N, Nunoi K, Kodama T, Nomiyama R, Iwase M, Fujishima M (1990) Lack of association between blood pressure and insulin in patients with insulinoma. J Hypertens 8: $479-482$

52. Hall JE, Brands MW, Kivlighn SD, Mizelle HL, Hildebrandt DA, Gaillard CA (1990) Chronic hyperinsulinaemia and blood pressure. Interaction with catecholamines. Hypertension (Dallas) 15: 519-527 